\title{
Research on demand-oriented Business English learning method
}

\author{
Yuan Zhou* \\ Shandong Vocational College of Foreign Affairs Translation, Weihai, Shandong, China
}

\begin{abstract}
Business English is integrated with visual-audio-oral English, which focuses on the application for English listening and speaking skills in common business occasions, and acquire business knowledge and improve skills through English. This paper analyzes the Business English Visual-audio-oral Course, and learning situation of higher vocational students' learning objectives, interests, vocabulary, listening and speaking, and focuses on the research of effective methods to guide the higher vocational students to learn Business English Visual-audio-oral Course, master Business English knowledge, and improve communicative competence of Business English.
\end{abstract}

Keywords: Business English; visual-audio-oral English; learning method

\section{INTRODUCTION}

According to statistics, about $34 \%$ of higher vocational colleges set up the major of Business English. Business English is one of the most widely used English in an international business environment, with its main feature of strong application. Business English Course is a main form to develop listening and speaking communicative competence. The teachers bring real and specific communicative demonstration to the students by the use of rich visual-audio-oral materials, and reproduce real business communication scenarios, thus more effectively grasping Business English knowledge, and developing Business English communication skills. This paper discusses how to learn Business English by the higher vocational students in combination with BEC.

\section{SIMPLE ANALYSIS OF BEC COURSE}

BEC is an important course for the higher vocational students majored with Business English, which is a visual-audio-oral course. Listening ability is enhanced by audio visual. The students can learn highly-targeted Business English, and acquire specialized and systematic training and learning, in order to develop and improve their listening, speaking, reading and writing ability required under business living environment,

*Corresponding author: andrea.83@163.com and acquire business information from a variety of materials, and possess the ability of analysis, understanding, induction, judgment and so on, and then effectively communicate in English and participate in business activities. To achieve the goal, the selection of the appropriate teaching materials plays an important role. BEC has rich, vivid and intuitive content and moderate difficulty, which highlights its application, and changes the traditional listening and speaking teaching mode (subject to "listening"). The teaching mode increases dimension to constitute many dimensions, and interacts with students combined with the "video" and "audio", so that the students can effectively learn English in a real business environment, and then acquire business knowledge through English, and improve professional skills.

\section{STATUS QUO OF HIGHER VOCATIONAL STUDENTS' BUSINESS ENGLISH LEARNING}

\subsection{Unclear learning objectives and lack of strong interest in learning}

The students in the third grade of higher vocational colleges are generally arranged for internships, so the students really learn knowledge in the first and second grade. After entering college, the students should take the exam of CET-4. They simply recite a lot of English vocabularies, and blindly do a lot of exercises, so 
that the students learn English just because they want to pass the exam, and the vast majority of students believe that the learning task in college is easier than that in the secondary school. They have a fear and rejection psychology for Business English Visual-audio-oral Course, and they learn Business English just because they want to pass the final exam, and they are unwilling to invest efforts to learn designedly.

\subsection{Few specialized vocabularies}

Few vocabularies are always an obstacle for many English learners to improve their English level. Vocabulary always plays a crucial role in the process of life and the practical application. Higher vocational students must master the necessary number of vocabulary to master listening, reading, speaking and writing skills, in order to rapidly improve English level. Due to the presence of a large number of specialized vocabularies and expressions in Business English, and the students are not familiar with them, it has a direct impact on the teachers' teaching effect and students' test scores.

\subsection{Listening comprehension problems}

The current students, college students, or higher vocational students, or middle school students, their listening ability is quite poor. There are many reasons for the students to have poor listening comprehension ability, including:

(1) Voice discrimination capability needs to be improved. The students are lack of special learning of voice knowledge and voice discrimination training, so they are difficult to make a rapid and correct response within a specified period.

(2) Relatively fast speed. The students are lack of practice or accustomed to communication with a slow speech, and rarely simulate the normal exchange training, so they could not adapt to the normal communication dialogue and large articles or phrases, and often translate the listening materials in mind to the native language, so that they could not keep up with the listening training or communication with others due to the presence of reaction time, and even feel that the normal speed is far beyond their scope of ability.

(3) Few vocabularies and rough grammar. Inadequate vocabularies and weak grammar knowledge has a direct impact on listening comprehension ability. Some students master a large amount of vocabulary, but they do not understand the fixed sentence pattern and special usage, resulting in misunderstanding. The students who master the grammar well will eventually have a poor performance due to the problem of vocabulary.

(4) Unfamiliarity with cultural background knowledge in other places. Due to misunderstanding of traditional custom in other places, the students do not understand the differences between Chinese and
Western cultures and their background knowledge. For English, it is mainly manifested as British English and American English, which brings some difficulties and obstacles in the listening comprehension.

(5) Psychological problems. Some students have a poor psychological quality. Combined with the impact of the above four factors, they could not concentrate in listening, resulting in tension, irritability and blank mind; or if they enter into the state, because they do not understand one or two sentences, they will be disheartened and despaired, leading to worse performance.

\subsection{Oral problem}

For higher vocational students, to learn English is to communicate with people easily. Therefore, it is particularly important to cultivate English listening and speaking ability. However, China's English teaching process always has the problem of "high scores and low abilities, time-consuming and low efficiency". In the teaching process, there are common phenomena of "paying attention to test scores, but ignoring ability training", and "paying attention to grammar, but neglecting spoken language". In the classroom, the teachers mainly adopt the "instilling" way, and rarely provide the opportunity of training oral ability for the students. The students are accustomed to "seeing" English, and lose confidence or even feel timid to "speak" English, and they also do not take time to practice English after class, so they gradually "fall behind" over the time. Therefore, the students have a certain reading and writing ability, but they are unable to correctly express their own ideas with the appropriate words in some occasions.

\section{ENGLISH LEARNING STRATEGIES}

To achieve the goal, the strategies play a vital role, and learning strategies are very important to achieve learning objectives. Confucius said that: "learning without thought is labor lost, thought without learning is perilous". It explains the relationship between "thinking" and "learning", and emphasizes the importance of learning strategy. Learning strategy is a complete concept. People began to research the learning strategies in the mid-1970s, which has been developed and extended in the 1980s and 1990s. At that time, with the increasing improvement of a second language learning theory, people of insight gradually realized the one-sidedness of only attaching importance to foreign language teaching method but ignoring the research of learning subject, so they shift the focus of research and learning from the teachers' teaching method to the students' learning method. Learning strategies are closely linked with the learning subject, so the learning strategies become an enduring topic in the research of foreign language teaching. 
Learning strategy is defined by Oxford as follows: "learning strategy is the theory abided by the learners in certain activities, which aims at making learning faster, easier, more fun, more efficient, more autonomous and more adaptable to new circumstance and new environment. "China's most influential monograph is English Learning Strategies published by Wen Qiufang in 1996. Strategy is divided into three categories: socio-emotional strategy, meta-cognition strategy and understanding strategy. We can appreciate that: learning strategy is a pivotal part in learning, and also characterized by complexity and diversity, because the students have great differences as a role of strategy subjects, and will certainly take different strategies; in addition, the learning objectives are also different, so the ways and means to achieve the objectives will inevitably be different.

In this way, Business English learning is classified based on the students' performance in English learning or the situation of mastering English knowledge. Combined with their own interests and characteristics, a set of tailored action program or the program of learning method shall be developed for a certain learning objective. The process of selection and customization of the students' English learning method is a process of continuously organizing, improving and summarizing their own learning concepts and learning methods. The students continuously and systematically adjust learning strategies according to their actual level. The learners use their own strategies and methods to improve their learning efficiency, so that they can have a targeted learning. Then, the students can learn by use of their own improved and summarized learning strategies, in order to achieve the effect of yield twice the result with half the effort psychologically or actually.

\section{ANALYSIS OF LEARNING STRATEGIES AND METHODS BY HIGHER VOCATIONAL STU- DENTS MAJORED WITH BUSINESS ENGLISH}

The students who learn higher vocational Business English are from ordinary full-time high school or vocational high school, and few students have a very solid foundation in English, so the vast majority of students have a poor foundation in English, especially listening and spoken language, who could not achieve the normal level of human communication. In terms of learning habits, the majority of students are accustomed to traditional classroom education in secondary school, with a relatively poor self-learning ability and passive learning, without initiative enthusiasm in learning, which is inseparable from a general trend of school education. As higher vocational students majored with Business English, most of them like English. They choose this major, just because of their love and passion for English, but just do not know how to learn English well. In other words, the students ma- jored with Business English have a common interest in English - like English, but they do not know how to learn English well, which is currently the largest learning obstacle for the students in this major. The training objective for the personnel majored with Business English is to train a batch of high-quality skill-oriented business personnel for society. The specific objectives required to achieve include strong English communicative competence, fast and accurate translation ability, skillful business operational capacity, strong communication skills and good computer application ability: proficiency in commonly used computer software, and network information search and processing capability, which is also a learning requirement and basic goal striving to achieve by the students majored with Business English.

\section{GUIDANCE FOR THE STUDENTS TO LEARN BUSINESS ENGLISH VISUAL-AUDIO-ORAL COURSE BY A CORRECT METHOD}

\subsection{To specify learning objectives and stimulate interest in learning}

The students are guided to understand that English learning objective is to use English for communication and exercise working ability, rather than seeking for a performance in the final exam. To learn Business English is to lay a foundation for future work in the business environment, rather than just passing the final exam. Interest is the best teacher, and teaching needs to stimulate the students' learning interest and attach importance to imparting knowledge teaching methods, in order to achieve the "teacher-led and student-centered" teaching activities. The teachers should cultivate the students' language competence and focus on developing the students' communicative competence. Organically combined with listening, speaking, reading and writing, the flexible teaching methods can be used in the classroom to vividly reproduce various business activity scenarios in the teaching materials, in order to let the students simulate and experience real scenarios, and stimulate the enthusiasm of students to actively participate in classroom communication tasks.

\subsection{To input specialized vocabulary and expression of Business English}

Language knowledge is a prerequisite for language communicative competence. Without solid language knowledge, it is impossible to obtain strong language communicative competence. To master a certain amount of specialized vocabulary and expression of Business English is a prerequisite for visual-audio-oral activities. Therefore, the teachers should require the students to obtaining specialized vocabulary and expression related to business activities. The teachers 
can prepare for the expressions related to the unit subject and then provide to the students.

\subsection{To improve the students' listening comprehension ability}

An important way to input language is listening. The listeners should boldly predict, discriminate, infer and acquire relevant critical information. The traditional teaching method of "listening to the recording, checking answers and then listening to recording again" has greatly affected listening teaching. In the classroom, the teachers should guide the students to learn to grasp the general idea of the materials and seize the key information tips, rather than understanding every word and sentence. Only through inputting vocabularies and language, the students may still not complete the visual-audio-oral tasks as required, and the teachers can list the keywords and general idea of expression of the visual-audio-oral materials, and guide the students to make prediction before listening.

\subsection{To create real business environment in the classroom}

An important way to input language is visual audio. The information input way provided by visual-audio means is vivid and concrete. Business English Visual-audio-oral Course should attach importance to the application for English listening and speaking skills in a variety of activities in reality. The multi-media visual-audio resources in the classroom can be used to create and simulate real business scenarios, and enable students to actively participate in and stimulate the brain to make reaction, which is conducive to better learn language knowledge and store in brain for a long time. Before playing video, the teachers should first lead the students to learn the relevant new words, phrases and sentences, and see the pictures to understand the main characters, scenes and predict the general idea. In the first round of playing, the teachers should guide the students to understand the general idea of the video, rather than completing the exercise tasks every time. Before the second round of playing, the teachers should let the students quickly browse, and accurately grasp critical information while viewing, and make some notes. In the third round of playing, the teachers provide some tips, and pause moderately the key points in video or let the students repeat thinking and recording. Finally, if necessary, the teachers can play video with subtitles, so that the students can have a deeper understanding of the video.

\subsection{To provide more opportunities for the students to "speak"}

Language is a communication tool. The ultimate goal of language teaching is to cultivate the students' ability to use language. The visual-audio-oral course should focus on coherent visual-audio-oral teaching. It is essential to allow the students to speak. Before implementation of speaking task, the teachers should first guide the students to repeatedly practice, learn and recite language points in the teaching materials, and then do visual-audio exercises. These activities of language input are conducive to the students' speaking. In the classroom, the students can be grouped freely to discuss and exercise dialogues orally according to the scenario provided by Roleplay after the video of teaching material. After exercising the language points and audio-visual exercises, the students simulate video to express the language knowledge learnt, and then carry out language output. The whole process from input to output shifts the classroom from the teachers teaching to the students' independent practice. The simulation of real process of communication effectively helps the students master the knowledge of Business English and improves oral communicative competence.

\section{CONCLUSION}

In summary, specify the teaching objectives and learning objectives, break the traditional old teaching philosophy in teaching, adopt the correct method to provide guidance combined with the actual situation of higher vocational students, create real business environment, focus on training listening and speaking ability, and also attach importance to business cultural knowledge can truly improve the students' Business English communication level. Learning to use learning strategy relies on common efforts of schools, teachers and students. The school should be committed to teaching by learning, and cultivate the students "learning" ability; the teachers should carefully analyze and research the students" "learning method" and adopt the teaching method that is applicable to higher vocational students, in order to promote the students' learning ability to think independently with increasingly innovative teaching methods; in the process of teaching, the teachers should also enable the students to understand the teachers' "teaching method" and demonstrate their own English "learning" method, so that the students can completely change their inherent self-awareness and English learning concepts unconsciously. The teachers can train and guide the students to develop English learning strategies in accordance with their own circumstances, in order to improve the students' English learning and management capabilities, and lay a foundation for lifelong English learning.

\section{REFERENCES}

[1] Ma Longhai. 2010. Business English Visual-audio-oral Course of New Vision. Beijing: Foreign Language Teaching and Research Press. 
[2] Zheng Jiasheng. 2010. Application for communicative approach in Higher Vocational Business English Visual-audio-oral Course. Beijing: Journal of Electric Power College, 27(10).

[3] Yang Lihua. 2010. Primary investigation of teaching reform of Higher Vocational Business English Visual-audio-oral Course. Education Science \& Culture, (22).
[4] Xing Yuan. 2006. On Higher Vocational Business English Visual-audio-oral Teaching. Journal of Taiyuan University, 7(4).

[5] Li Peie. 2009. Strengthening cultivation of higher vocational students' oral competence in classroom teaching. Exam Week, (35). 